\title{
Correlation of diagnostic efficacy of unhealthy cervix by cytology, colposcopy and histopathology in women of rural areas
}

\author{
Richa D. Chaudhary*, Saunitra A. Inamdar, Chella Hariharan
}

Department of Obstetrics and Gynaecology, Datta Meghe Institute of Medical Sciences, Wardha-442004, Maharashtra, India

Received: 19 October 2013

Accepted: 27 October 2013

\section{*Correspondence:}

Dr. Richa D. Chaudhary

E-mail: richachaudhary17@gmail.com

(C) 2014 Chaudhary RD et al. This is an open-access article distributed under the terms of the Creative Commons Attribution Non-Commercial License, which permits unrestricted non-commercial use, distribution, and reproduction in any medium, provided the original work is properly cited.

\begin{abstract}
Background: The objective was to assess the sensitivity and specificity of pap smear and colposcopy and to study the socio demographic parameters of women with unhealthy cervix.

Methods: This was a prospective observational study conducted from August 2011 - August 2013 in the Department of Obstetrics and Gynaecology. Pap smear was performed by the conventional method and colposcopy was done for all 200 sexually active women who came with complaints of discharge per vagina, inter menstrual or post coital bleeding. Colposcopy results were analysed. Final correlation of pap smear and colposcopy were based on histopathology.

Results: There were 200 samples that were suitable for statistical analysis. The sensitivity of colposcopy was $79.37 \%$, specificity $81.02 \%$, positive predictive value $65.79 \%$, negative predictive value $89.52 \%$ respectively and accuracy was $80.5 \%$. Pap smear had a sensitivity of $25.4 \%$, specificity of $99.27 \%$, positive predictive value of $94.12 \%$, negative predictive value of $74.32 \%$, and accuracy of $76.0 \%$ respectively.

Conclusions: Pap smear had a poorer sensitivity compared to Colposcopy but a better specificity than colposcopy. Hence it may be better to utilise both tests as they complement each other in screening of premalignant lesions of cervix.
\end{abstract}

Keywords: Pap smear, Colposcopy, Premalignant lesion of cervix, Suspicious looking cervix, Atypical squamous cell of undetermined significance, Negative for intra epithelial lesion or malignancy

\section{INTRODUCTION}

It is very common for the gynaecologists who work in tertiary care institutes in the developing countries to get referrals from practitioners and peripheral health centres for patients with a clinical diagnosis of an "unhealthy cervix". If abnormal growth, ulcer, or vasculature is present, the cervix is clinically diagnosed as unhealthy. ${ }^{2}$ an "unhealthy cervix" or grossly abnormal cervix can harbour premalignant cervical lesions or invasive carcinoma. ${ }^{3}$ The naked eye evaluation of unhealthy cervix is deceptive sometimes and it so happens that intraepithelial lesions are considered as simple cases of erosion due to inflammation.
The basic purpose of screening is to sort out from a large group of healthy persons those likely to have the disease or at increased risk of the disease under study and to bring those who are 'apparently abnormal' under medical supervision and treatment.

The long pre - clinical stage of cervical cancer during which precursor lesions can be treated conservatively and successfully make cervical cancer an ideal target for screening and treatment. Success of screening programmes is limited in the villages of India wherein females are illiterate, health infrastructure is mediocre, and cervical screening is unknown. ${ }^{4}$ 
Cancer uterine cervix is a serious health problem in India. ${ }^{5}$ India which accounts for the world's one sixth of the world's population also bears one fifth of the burden of cervical cancer. There are approximately 1,30,000 new cases of cervical cancer every year and the disease is responsible for $20 \%$ of all the female deaths. ${ }^{6}$ In India, every $7^{\text {th }}$ minute a woman dies due to cervical cancer. It is predicted that figures are expected to double by 2020 if no action is taken.

Cancer cervix accounts for $7 \%$ of all malignancies in developed countries which is in sharp contrast to $24 \%$ in developing countries. The disparity is almost attributed to primarily differences in screening and treatment of precancerous lesion. ${ }^{8}$

The diagnostic algorithm of various organized screening programmes consists of cytology \& colposcopy (which help in detecting the abnormality) \& which can be established by histology (grade of lesion).

Colposcopy is an optical method of visualizing lower female genital tract under bright illumination under stereoscopic vision. It is a simple non invasive OPD procedure which helps in determining the location, size and extent of abnormal cervical lesions and serves for detecting the site for biopsies and for selecting the most appropriate treatment.

Colposcopy is complimentary to cytology. Cytology (pap smear) is the lab method while colposcopy is the clinical method of detection. Colposcopy is more than a simple intermediate link between cytologic screening and histologic diagnosis. ${ }^{9}$ Colposcopic guided biopsy of suspicious areas provides the final diagnosis and is taken as the gold standard in diagnosis of intra epithelial lesions.

Pap smear has become a routine method of cervical cancer screening. Also, in a developing country like India, cytology based screening programmes are difficult to organize because of absence of trained manpower, infrastructure, logistics, costs involved and has other limitations like low sensitivity and high false negative rates. $^{10}$

This has led to a search for alternative screening methods that can be more cost-effective for application in lowresources settings. Thus this study was done to evaluate the role of colposcopy in the detecting preinvasive and invasive lesions in clinically unhealthy cervix in our rural setup.

\section{METHODS}

Material of the present study was collected from 200 cases visiting the Department of Obstetrics and Gynaecology Acharya Vinoba Bhave Rural Hospital, Sawangi (Wardha) from August 2011 - August 2013.

\section{Inclusion Criteria}

- Sexually active women with "unhealthy cervix" (clinically suspicious cervix, cervical erosions, hypertrophied cervix) on per speculum examination.

\section{Exclusion Criteria}

- Unmarried women

- Pregnant women

- Diagnosed cases of carcinoma cervix

- Post hysterectomy cases

\section{Methodology}

Written and informed consent was taken from all the patients after brief explanation of the procedure. Ethical clearance was obtained from institute's ethical clearance committee. A careful history including demographic data like age, socioeconomic status, education, parity, age at marriage of the patient was taken.

After preliminary inspection of the cervix, pap smear was taken using Ayre's spatula and the scrapings were fixed by dipping in the jar containing equal parts of $95 \%$ ethyl alcohol and ether.

Revised Bethesda system ${ }^{11}$ was used for describing pap smear results. Pap smear results were classified as NILM, ASC (US), LSIL, HSIL and Carcinoma. LSIL and above lesions were considered as positive on cytology.

For colposcopic examination Dr Camscope colposcope model $150 \mathrm{FC}$ with magnification between $10 \mathrm{X}$ to $12.5 \mathrm{X}$ was used. Colposcopic examination included:

- Direct examination of cervix with green filter and saline application.

- Examination of the cervix after test with $3 \%$ acetic acid, seeing the junction of squamous cell, erosion, papillary lesions, aceto-white areas and vascular design.

- Examination of the cervix after Lugol test in which normal squamous epithelium, which contains glycogen, turns brown.

Findings were recorded and colposcopy diagnosis was made based on Modified Colposcopic Reid Index. ${ }^{12,13}$

$$
\text { Reid's Colposcopic Index /Score [RCI]. }{ }^{12,13}
$$

\begin{tabular}{|ll|}
\hline Score & Colposcopic findings \\
\hline $0-2$ & Benign Inflammation \\
\hline $3-5$ & Low grade lesion \\
\hline $6-8$ & High grade lesion \\
\hline$>8$ & Invasive Lesion \\
\hline
\end{tabular}




\begin{tabular}{|llll|}
\hline $\begin{array}{l}\text { Colposcopy } \\
\text { Sign }\end{array}$ & Score 0 & Score 1 & Score 2 \\
\hline Margin & $\begin{array}{l}\text { Condylomatous or micropapillary contour. } \\
\text { Flocculated or feathered, jagged, angular, } \\
\text { satellite lesion, AWA beyond original } \\
\text { squamo-columnar junction. }\end{array}$ & $\begin{array}{l}\text { Regular lesion with } \\
\text { smooth indistinct } \\
\text { borders. }\end{array}$ & $\begin{array}{l}\text { Rolled, peeling edges, sharp } \\
\text { margins. }\end{array}$ \\
\hline Colour & $\begin{array}{l}\text { Shiny, snow white, areas of faint (semi } \\
\text { transparent) whitening. }\end{array}$ & $\begin{array}{l}\text { intermediate shade } \\
\text { (Shiny but grey }\end{array}$ & Dull, oyster grey \\
\hline Vessels & $\begin{array}{l}\text { Uniform, fine caliber non dilated capillary } \\
\text { loops fine punctuation or mosaic }\end{array}$ & $\begin{array}{l}\text { Absence of surface } \\
\text { vessels }\end{array}$ & $\begin{array}{l}\text { Definite, coarse punctuation } \\
\text { or mosaic. }\end{array}$ \\
\hline $\begin{array}{l}\text { Iodine } \\
\text { staining }\end{array}$ & $\begin{array}{l}\text { Any lesion staining Mahagony brown; } \\
\text { mustard yellow staining by a minor lesion } \\
\text { (by first three criteria). }\end{array}$ & $\begin{array}{l}\text { Partial iodine } \\
\text { uptake(mottled } \\
\text { pattern) }\end{array}$ & $\begin{array}{l}\text { Mustard Yellow staining of a } \\
\text { significant lesion (an acetowhite } \\
\text { area scoring 3 or more points by } \\
\text { the first three criteria) }\end{array}$ \\
\hline
\end{tabular}

Low grade lesions and above were considered as positive on colposcopy. Unsatisfactory smears and unsatisfactory colposcopy were excluded from the study.

\section{Colposcopy guided biopsy}

Biopsy was taken under colposcopy guidance by punch biopsy forceps or four quadrant biopsy. The specimen was sent for histopathological examination in formalin solution and slides were analysed by consultant pathologists.

Biopsy results were categorized as ${ }^{14}$ cervicitis with metaplasia, LSIL (correlating to Mild dysplasia), HSIL (correlating to Moderate to severe dysplasia, carcinoma in situ) and carcinoma.

Final correlation of pap smear and colposcopy were based on histopathology.

\section{RESULTS}

White discharge per vaginum was the most common complaint followed by pelvic pain in $39 \%$ cases (Table 1 ).

Table 1: Presenting Complaints of 200 Cases.

\begin{tabular}{|llll|}
\hline $\begin{array}{l}\text { Sr. } \\
\text { No }\end{array}$ & Symptoms & $\begin{array}{c}\text { No. of } \\
\text { Cases }\end{array}$ & Percentage \\
\hline 1. & $\begin{array}{l}\text { White Discharge Per } \\
\text { Vaginum }\end{array}$ & 78 & $39.0 \%$ \\
\hline 2. & Pain in Abdomen & 41 & $20.5 \%$ \\
\hline 3. & Menstrual Disorders & 35 & $17.5 \%$ \\
\hline 4. & $\begin{array}{l}\text { Postmenopausal } \\
\text { Bleeding }\end{array}$ & 30 & $15 \%$ \\
\hline 5. & $\begin{array}{l}\text { Burning Micturition } \\
\text { (UTI) }\end{array}$ & 14 & $7 \%$ \\
\hline 6. & Itching Over Genitals & 2 & $1 \%$ \\
\hline & Total & 200 & $100.0 \%$ \\
\hline
\end{tabular}

On per speculum examination, cervical erosion was the most common clinical presentation in $86.5 \%$ cases (Table 2).

Table 2: Per speculum examination of the cervix of 200 cases.

\begin{tabular}{|lll|}
\hline Clinical finding & Number & $\%$ \\
\hline Cervical erosion & 173 & $86.5 \%$ \\
\hline Hypertrophied cervix & 23 & $11.5 \%$ \\
\hline Suspicious looking cervix & 04 & $2 \%$ \\
\hline
\end{tabular}

Out of the 200 cases, $124(62 \%)$ cases were having benign inflammatory lesion colposcopically and 76 (38\%) were atypical colposcopically. Out of these atypical cases, $19 \%$ cases were low grade lesions, $18 \%$ cases were high grade lesions and $1 \%$ were invasive carcinoma (Table 3).

Table 3: Distribution of colposcopic lesions.

\begin{tabular}{|llll|}
\hline $\begin{array}{l}\text { Sr. } \\
\text { No }\end{array}$ & $\begin{array}{l}\text { Reid Colposcopic } \\
\text { Score }\end{array}$ & $\begin{array}{l}\text { No. of } \\
\text { Cases }\end{array}$ & Percentage \\
\hline 1. & $\begin{array}{l}\text { 0-2 (Benign } \\
\text { Inflammatory) }\end{array}$ & 124 & $62 \%$ \\
\hline 2. & $\begin{array}{l}\text { 3-5 (Low Grade } \\
\text { Lesion })\end{array}$ & 38 & $19 \%$ \\
\hline 3. & $\begin{array}{l}\text { 6- 8 (High Grade } \\
\text { Lesion ) }\end{array}$ & 36 & $18 \%$ \\
\hline 4. & $>8$ (Carcinoma) & 2 & $1 \%$ \\
\hline & Total & 200 & 100 \\
\hline
\end{tabular}

NILM was encountered in maximum number of cases (166). 8.5\% cases were ASC (US) Atypical Squamous Cells of Undetermined Significance, $5 \%$ were LSIL, $2.5 \%$ were HSIL and only $1 \%$ were carcinoma (Table 4 ). 
Table 4: Distribution of various grades of cytology.

\begin{tabular}{|llll|}
\hline $\begin{array}{l}\text { Sr. } \\
\text { No }\end{array}$ & Types of Smear & $\begin{array}{l}\text { No. of } \\
\text { Cases }\end{array}$ & Percentage \\
\hline 1. & NILM & 166 & $83 \%$ \\
\hline 2. & ASC(US) & 17 & $8.50 \%$ \\
\hline 3. & LSIL & 10 & $5.0 \%$ \\
\hline 4. & HSIL & 5 & $2.5 \%$ \\
\hline 5. & Carcinoma & 2 & $1.0 \%$ \\
\hline & Total & 200 & 100.0 \\
\hline
\end{tabular}

Out of 200 cases, $68.5 \%$ cases were cervicitis (with metaplasia), $16.5 \%$ were LSIL (mild dysplasia), $10 \%$ were HSIL (moderate - severe dysplasia) and 5\% were invasive carcinoma. None of the histopathological report was suggestive of carcinoma in situ (Table 5).

Table 5: Distribution of various grades of histopathology.

\begin{tabular}{|llll|}
\hline $\begin{array}{l}\text { Sr. } \\
\text { no }\end{array}$ & Histopathology report & $\begin{array}{l}\text { No. of } \\
\text { cases }\end{array}$ & $\%$ \\
\hline 1. & Cervicitis with metaplasia & 137 & $68.5 \%$ \\
\hline 2. & LSIL (Mild dysplasia) & 33 & $16.5 \%$ \\
\hline 3. & $\begin{array}{l}\text { HSIL (Moderate - severe } \\
\text { dysplasia) }\end{array}$ & 20 & $10 \%$ \\
\hline 4. & Carcinoma & 10 & $5 \%$ \\
\hline & Total & 200 & 100.0 \\
\hline
\end{tabular}

Overall the sensitivity of pap smear for detecting lesions above LSIL (mild dysplasia and above) came out to be $25.40 \%$, specificity $99.27 \%$, positive predictive value $94.12 \%$, negative predictive value $74.32 \%$ respectively. Accuracy of pap smear in our study was $76 \%$ (Table 6, 7).

Table 6: Correlation of Pap smear with histopathology.

\begin{tabular}{|lllll|}
\hline \multicolumn{5}{|c|}{ Histopathological findings } \\
Pap smear & $\begin{array}{l}\text { Chronic } \\
\text { cervicitis } \\
\text { with } \\
\text { metaplasia }\end{array}$ & $\begin{array}{l}\text { LSIL } \\
\text { (mild } \\
\text { dysplasia) }\end{array}$ & $\begin{array}{l}\text { HSIL } \\
\text { (moderate }\end{array}$ & $\begin{array}{l}\text { Ca } \\
\text { severe } \\
\text { dysplasia) }\end{array}$ \\
\hline NILM (166) & $132(66 \%)$ & $20(10 \%)$ & $14(7 \%)$ & $0(0 \%)$ \\
\hline $\begin{array}{l}\text { ASC(US) } \\
(17)\end{array}$ & $4(2 \%)$ & $12(6 \%)$ & $0(0 \%)$ & $1(0.5 \%)$ \\
\hline LSIL (10) & $0(0 \%)$ & $1(0.5 \%)$ & $2(1 \%)$ & $7(3.5 \%)$ \\
\hline HSIL (5) & $1(0.5 \%)$ & $0(0 \%)$ & $3(1.5 \%)$ & $1(0.5 \%)$ \\
\hline $\begin{array}{l}\text { Carcinoma } \\
(2)\end{array}$ & $0(0 \%)$ & $0(0 \%)$ & $1(0.5 \%)$ & $1(0.5 \%)$ \\
\hline Total (200) & $\begin{array}{l}137 \\
(68.5 \%)\end{array}$ & $\begin{array}{l}33 \\
(16.5 \%)\end{array}$ & $20(10 \%)$ & $10(5 \%)$ \\
\hline x2-value & 173.4 & & & \\
\hline p-value & $<0.0001$, Significant & & \\
\hline
\end{tabular}

Table 7: Sensitivity and specificity of Pap smear.

\begin{tabular}{|c|c|c|c|c|}
\hline \multirow{2}{*}{ Pap Smear } & \multicolumn{2}{|c|}{ Histopathology } & «2-value & p-value \\
\hline & Positive & Negative & \multirow{4}{*}{33.76} & \multirow{4}{*}{$\begin{array}{l}\mathrm{P}<0.0001 \\
\text { Significant }\end{array}$} \\
\hline Positive & 16 & 1 & & \\
\hline Negative & 47 & 136 & & \\
\hline Total & 63 & 137 & & \\
\hline
\end{tabular}

\begin{tabular}{|lll|}
\hline & $\%$ & $95 \%$ CI \\
\hline Sensitivity & 25.40 & $15.27-37.94$ \\
\hline Specificity & 99.27 & $96.00-99.98$ \\
\hline PPV & 94.12 & $71.31-99.85$ \\
\hline NPV & 74.32 & $67.35-80.46$ \\
\hline Accuracy & $76.00 \%$ & \\
\hline
\end{tabular}

In our study the sensitivity of colposcopy for detecting low grade lesions and above came out to be $79.37 \%$, specificity $81.02 \%$, positive predictive value $65.79 \%$, negative predictive value $89.52 \%$ respectively. Accuracy of colposcopy in our study was $80.50 \%$ (Table 8, 9).

Table 8: Correlation of colposcopy with histopathology.

\begin{tabular}{|c|c|c|c|c|}
\hline \multirow[b]{2}{*}{$\begin{array}{l}\text { Reid } \\
\text { Colposcopy } \\
\text { score }\end{array}$} & \multicolumn{4}{|c|}{ Histopathology } \\
\hline & $\begin{array}{l}\text { Cervicitis } \\
\text { (with } \\
\text { metaplasia) }\end{array}$ & $\begin{array}{l}\text { LSIL } \\
\text { (Mild } \\
\text { dysplasia) }\end{array}$ & $\begin{array}{l}\text { HSIL } \\
\text { (Moderat } \\
\text { e - severe } \\
\text { dysplasia) }\end{array}$ & Ca \\
\hline $\begin{array}{l}0-2 \text { (Benign } \\
\text { Inflammatory) } \\
124\end{array}$ & $111(55.5 \%)$ & $12(6 \%)$ & $1(0.5 \%)$ & $0(0 \%)$ \\
\hline $\begin{array}{l}3-5 \text { (Low } \\
\text { grade lesion) } \\
38\end{array}$ & $18(9 \%)$ & $15(7.5 \%)$ & $4(2 \%)$ & $\begin{array}{l}1 \\
(0.5 \%)\end{array}$ \\
\hline $\begin{array}{l}6-8 \text { (High } \\
\text { grade lesion) } \\
36\end{array}$ & $8(4 \%)$ & $6(3 \%)$ & $15(7.5 \%)$ & $\begin{array}{l}7 \\
(3.5 \%)\end{array}$ \\
\hline$>8(\mathrm{Ca}) 2$ & $0(0 \%)$ & $0(0 \%)$ & $0(0 \%)$ & $2(1 \%)$ \\
\hline Total (200) & $137(68.5 \%)$ & $33(16.5 \%)$ & $20(10 \%)$ & $10(5 \%)$ \\
\hline$\aleph 2$-value & 165.2 & & & \\
\hline p-value & $\mathrm{P}<0.0001, \mathrm{Si}$ & nificant & & \\
\hline
\end{tabular}


Table 9: Sensitivity and specificity of colposcopy.

\begin{tabular}{|c|c|c|c|c|}
\hline \multirow{2}{*}{ Colposcopy } & \multicolumn{2}{|c|}{ Histopathology } & $\begin{array}{l}\text { «2- } \\
\text { value }\end{array}$ & p-value \\
\hline & Positive & Negative & \multirow{4}{*}{66.79} & \multirow{4}{*}{$\begin{array}{l}\mathrm{P}<0.0001 \\
\text { Significant }\end{array}$} \\
\hline Positive & 50 & 26 & & \\
\hline Negative & 13 & 111 & & \\
\hline Total & 63 & 137 & & \\
\hline
\end{tabular}

\begin{tabular}{|ll|l|}
\hline & $\%$ & $95 \%$ CI \\
\hline Sensitivity & 79.37 & $67.30-88.53$ \\
\hline Specificity & 81.02 & $73.44-87.21$ \\
\hline PPV & 65.79 & $54.01-76.29$ \\
\hline NPV & 89.52 & $82.74-89.30$ \\
\hline Accuracy & $80.50 \%$ & \\
\hline
\end{tabular}

The incidence of preinvasive lesions - LSIL (mild dysplasia) and HSIL (moderate - severe dysplasia) were $16.5 \%$ and $10 \%$ respectively while the incidence of invasive lesions was $5 \%$ in our study (Table 10).

Table 10: Incidence (\%) of preinvasive and invasive lesions.

\begin{tabular}{|ll|}
\hline Total no of patients & 200 \\
\hline Preinvasive Lesions & $53(26.5 \%)$ \\
\hline LSIL & $33(16.5 \%)$ \\
\hline HSIL & $20(10 \%)$ \\
\hline Invasive lesions & $10(5 \%)$ \\
\hline
\end{tabular}

\section{DISCUSSION}

Sensitivity of Pap smear was $25.40 \%$; specificity was $99.27 \%$, positive predictive value $94.12 \%$, negative predictive value $74.32 \%$ for diagnosing LSIL and above lesions.

On comparison with other studies the following results were obtained.

\begin{tabular}{|lllll|}
\hline Study & Sensitivity & Specificity & PPV & NPV \\
\hline $\begin{array}{l}\text { Present } \\
\text { study }\end{array}$ & $25.40 \%$ & $99.27 \%$ & $94.12 \%$ & $74.32 \%$ \\
\hline $\begin{array}{l}\text { Ashmita \& } \\
\text { Shakuntala } \\
\text { et al }\end{array}$ & $19.51 \%$ & $83.33 \%$ & $80.00 \%$ & $23.26 \%$ \\
\hline $\begin{array}{l}\text { Mallur } \\
\text { et al }\end{array}$ & $41.66 \%$ & $81.2 \%$ & $86.21 \%$ & $78.26 \%$ \\
\hline Jain et al $^{17}$ & $78 \%$ & $91.1 \%$ & $26.9 \%$ & $11.3 \%$ \\
\hline
\end{tabular}

The accuracy of pap smear was $76 \%$ in our study which is comparable to Bhatla et $\mathrm{al}^{18}(89 \%)$, Maziah et $\mathrm{al}^{19}$ (90\%), Jain et $\mathrm{al}^{17}$ (2010) $73.2 \%$. However Malur PR ${ }^{16}$ et al and Ashmita and Shakuntala ${ }^{15}$ et al concluded the accuracy of Pap smear to be $40 \%$ and $33.96 \%$ respectively.

Sensitivity of colposcopy was $79.37 \%$; specificity was $81.02 \%$, positive predictive value $65.79 \%$, negative predictive value $89.52 \%$ for diagnosing low grade and above lesions.

On comparison with other studies the following results were obtained.

\begin{tabular}{|lllll|}
\hline Study & Sensitivity & Specificity & PPV & NPV \\
\hline Present study & $79.37 \%$ & $81.02 \%$ & $65.79 \%$ & $89.52 \%$ \\
\hline $\begin{array}{l}\text { Ashmita \& } \\
\text { Shakuntala } \\
\text { et al }\end{array}$ & $90.24 \%$ & $72.73 \%$ & $66.67 \%$ & $86.54 \%$ \\
\hline $\begin{array}{l}\text { Mallur PR } \\
\text { et al }\end{array}$ & $80 \%$ & $81.54 \%$ & $66.66 \%$ & $89.83 \%$ \\
\hline $\begin{array}{l}\text { Pimple SA et } \\
\text { al., in 2010 }\end{array}$ & $74.5 \%$ & $92.9 \%$ & & \\
\hline
\end{tabular}

The accuracy of colposcopy in our study was $80.50 \%$ which is in parallel to the findings of Maziah et $\mathrm{al}^{19}$ (94\%), Ashmita and Shakuntala ${ }^{15}$ et al (86.54\%), Mallur et $\mathrm{al}^{16}(80 \%)$ and Ancuţa Boicea et $\mathrm{al}^{21}(98.3 \%)$. Literature is replete with data pertaining to the sensitivity of Pap smear and colposcopy ranging from $27 \%$ to $50 \%$ vs $44 \%-89 \%$ respectively. Specificity of Pap smear and colposcopy ranging from $19.5 \%-98.71 \%$ vs $52 \%-93.4 \%$ respectively. $^{22,23}$

Overall Pap smear had a poor sensitivity compared to colposcopy, $25.40 \%$ vs $79.37 \%$ respectively. Pap had a better specificity though not significantly compared to colposcopy, $99.27 \%$ vs $81.02 \%$ respectively.

The incidence of preinvasive lesion in our study was $26.5 \%$. The incidence of premalignant lesions of the cervix range in various studies range from $8.15 \%$ to $35.2 \%{ }^{15}$

The main goal of cervical screening is to identify women with moderate - severely dysplastic lesions (HSIL) $(10 \%$ women in our study), which are considered to be the true precursors of invasive cancer and require treatment, thus ultimately decreasing morbidity and mortality due to cervical cancer.

\section{CONCLUSION}

The results from the current study support the claim to perform combination screening tests as part of routine screening for cervical cancer screening rather than pap smear alone in order to detect maximum number of 
cases with accuracy and minimal loss of patients to follow up.

Funding: No funding sources

Conflict of interest: None declared

Ethical approval: The study was approved by the Institutional Ethics Committee

\section{REFERENCES}

1. Arora R, K Vijaya, Habeebullah S, O. Asha. Colposcopic evaluation of unhealthy cervix. J Obstet Gynecol Ind 2000;50:102-3.

2. Dasari P. A grossly abnormal cervix: Evidence for using colposcopy in the absence of a squamous intraepithelial lesion by the conventional Papanicolau's test. Journal of Gynecologic Surgery. 2011 March;27(1).

3. Mona E., Mohamed N., Hanafi N., Orief H., Mohamed S. Prevalence of high risk human papillomavirus types $16 / 18$ in cytologically abnormal cervical smears in Alexandria, Egypt - A cytological and molecular study, Middle East Fertility Society Journal. Jul 2013.

4. Gajalakshmi CK, Krishnamurthi S, Ananth R, Shanta V. Cervical cancer screening in Tamil Nadu, India: A feasibility study of training the village health nurse, Cancer Causes Control 1996;7:520-4.

5. World Health Organisation. Comprehensive cervical cancer control: a guide to essential practice. Geneva, WHO, 2006.

6. Kumar K., Iyer v.k., Bhatla N., Kriplani A., Verma K. Comparative evaluation of smear cytology and hybrid capture for the diagnosis of cervical cancer. Indian J Med Res 2007;126:39-44.

7. Rasha D, Jyothi V, Martha J. A strategic assessment of cervical cancer prevention and treatment strategies. Reproductive Health 2005;2:11.

8. Ries L, Eisner MP, Kosary CL, et al, SEER Cancer Statistics Review, 1975-2002. Bethesda, MD: National Cancer Institute, 2004.

9. Mahboobeh S., Diane S., Philip E.C. Cervical cancer prevention- Cervical screening: Science in evolution. Obstet Gynecol Clin N Am 2007;34:73960.

10. Dinshaw KA, Shastri SS, Patil SS. Cancer Control Programme in India: challenges for the new Millennium; Health Administrator Vol: XVII (1): $10-13$.

11. Addis IB, Hatch KD, Berek JS. Intraepithelial disease of the cervix, vagina and vulva. Berek and Novak's Gynaecology $14^{\text {th }}$ Edn Lippincott Williams and Wilkins 2007;573.
12. Reid R, Scalzi P. Genital warts and cervical cancer. VII. An improved colposcopic index for differentiating benign papilloma viral infections from high-grade cervical intraepithelial neoplasia. Am J Obstet Gynecol 1985;153:611-8.

13. Sellors JW, Sankaranarayanan R (2003). Colposcopy and Treatment on Cervical Intraepithelial Neoplasia: A Beginners' Manual. IARC Press, Lyon, France.

14. Robbins and Cotran, Kumar, Abbas, Fausto, Aster. Pathologic basis of disease, Elsevier publisher, 8th edition; 2011:1020.

15. Ashmita D, Shakuntala PN, Rao SR, et al. Comparison and Correlation of PAP Smear, Colposcopy and Histopathology in Symptomatic Women and Suspicious Looking Cervix in a Tertiary Hospital Care Centre. Int J Health Sci Res. 2013;3(5):50-59.

16. Mallur PR, Desai BR, Anita D, Geeta D, Bhavana S, Pallav G. Sequential Screening with Cytology and Colposcopy in Detection of Cervical Neoplasia. J. South Asian Feder Obst Gynae 2009;1(3):45-8.

17. Jain V, Vyas AS. Cervical Neoplasia-CytoHistological Correlation (Bethesda System) A Study of 276 Cases. J Cytol Histol 2010;1:106.

18. Bhatla N, Mukhopadhyay A, Kriplani A, Pandey RM, Gravitt EP, Shah KV, et al. Evaluation of adjunctive tests for cervical cancer screening in low resource settings. Indian J Cancer 2007;44:51-5.

19. Maziah AM, Sharifah NA, Yahya A. Comparative study of cytologic and colposcopic findings in preclinical cervical cancer. Malays J Pathol 1991;13(2):105-8.

20. Pimple SA, Amin G, Goswami S, Shastri SS. Evaluation of colposcopy vs cytology as secondary test to triage women found positive on visual inspection test. Indian J Cancer 2010;47(3):308-13.

21. Boicea A, Pătraşcu A, Surlin V, Iliescu D, Schenker M, Chiuţu L. Correlations between colposcopy and histologic results from colposcopically directed biopsy in cervical precancerous lesions. Rom J Morphol Embryol 2012;53(3 Suppl):735-41.

22. Bhalerao A, Kulkarni S, Ghike S, Kawthalkar A, Joshi S. Correlation of pap smear, colposcopy and histopathology in women with unhealthy cervix. J South Asian Feder Obst Gynae 2012;4(2):97-8.

23. Massad LS, Collins YC. Strength of correlations between colposcopic impression and biopsy histology. Gynecol Oncol. 2003 Jun;89(3):424-8.

DOI: $10.5455 / 2320-1770 . i j r \operatorname{cog} 20140343$

Cite this article as: Chaudhary RD, Inamdar SA, Hariharan C. Correlation of diagnostic efficacy of unhealthy cervix by cytology, colposcopy and histopathology in women of rural areas. Int $\mathbf{J}$ Reprod Contracept Obstet Gynecol 2014;3:213-8. 